\title{
Nitric Oxide Protects PC12 Cells from Serum Deprivation-Induced Apoptosis by cGMP-Dependent Inhibition of Caspase Signaling
}

\author{
Young-Myeong Kim, ${ }^{1,2}$ Hun-Taeg Chung, ${ }^{3}$ Sung-Soo Kim, ${ }^{1}$ Jeong-A Han, ${ }^{1}$ Yeong-Min Yoo, ${ }^{1}$ Ki-Mo Kim, ${ }^{1}$ \\ Gwang-Hoon Lee, ${ }^{4}$ Hye-Young Yun, ${ }^{4}$ Angela Green, ${ }^{2}$ Jianrong Li, ${ }^{2}$ Richard L. Simmons, ${ }^{2}$ \\ and Timothy R. Billiar ${ }^{2}$ \\ ${ }^{1}$ Department of Molecular and Cellular Biochemistry, College of Medicine, Kangwon National University, Chunchon, \\ Kangwon-do, Korea, ${ }^{2}$ Department of Surgery, University of Pittsburgh, Pittsburgh, Pennsylvania 15213, ${ }^{3}$ Department of \\ Immunology, Wonkwang University, College of Medicine, Iksan, Chunbug, Korea, and ${ }^{4}$ Department of Biochemistry, \\ College of Medicine, Chung-Ang University, Seoul, Korea
}

Although nitric oxide (NO) induces neuronal cell death under some conditions, it also can prevent apoptosis resulting from growth factor withdrawal. We investigated the molecular mechanism by which NO protects undifferentiated and differentiated PC12 cells from trophic factor deprivation-induced apoptosis. PC12 cells underwent apoptotic death in association with increased caspase-3-like activity, DNA fragmentation, poly(ADPribose) polymerase (PARP) cleavage, and cytochrome c release after $24 \mathrm{hr}$ of serum withdrawal. The apoptosis of PC12 cells was inhibited by the addition of NO-generating donor S-nitroso- $N$-acetylpenicillamine (SNAP) $(5-100 \mu \mathrm{M})$ and the specific caspase-3-like protease inhibitor Ac-Asp-Glu-Val-Aspaldehyde (Ac-DEVD-cho) but not the YVADase (or caspase-1like protease) inhibitor $N$-acetyl-Tyr-Val-Ala-Asp-aldehyde (AcYVAD-cho). SNAP and Ac-DEVD-cho prevented the increase in DEVDase (caspase-3-like protease) activity. The SNAPmediated suppression of DEVDase activity was only minimally reversed by the incubation of cell lysate with dithiothreitol, indicating that NO did not S-nitrosylate caspase-3-like proteases in PC12 cells. Western blot analysis showed that NO inhibited the proteolytic activation of caspase-3. The cGMP analog 8-bromo-cGMP (8-Br-cGMP) blocked apoptotic cell death, caspase- 3 activity and activation, and cytochrome c release. The soluble guanylyl cyclase inhibitor $1-\mathrm{H}$-oxodiazol[1,2,4]-[4,3-a] quinoxaline-1-one (CODQ) significantly attenuated NO-mediated, but not 8-Br-cGMP-dependent, inhibition of apoptotic cell death, PARP cleavage, cytochrome c release, and DEVDase activity. Furthermore, the protein kinase $\mathrm{G}$ inhibitor KT5823 reversed both SNAP- and 8-Br-cGMP-mediated anti-apoptotic events. All these apoptotic phenomena were also suppressed by NO production through neuronal NO synthase gene transfer into PC12 cells. Furthermore, similar findings were observed in differentiated PC12 cells stimulated to undergo apoptosis by NO donors and NGF deprivation. These findings indicate that NO protects against PC12 cell death by inhibiting the activation of caspase proteases through cGMP production and activation of protein kinase $\mathrm{G}$.

Key words: nitric oxide; soluble guanylyl cyclase; protein kinase G; cGMP; caspase; apoptosis; PC12
Programmed cell death, or apoptosis, is a normal physiological process that occurs during embryonic development, as well as in the maintenance of tissue homeostasis. Apoptosis can be induced in response to various cytotoxic stimuli, including Fas, tumor necrosis factor- $\alpha(\mathrm{TNF} \alpha)$, and serum or growth factor withdrawal (Steller, 1995; Thompson, 1995). These stimuli activate a series of tightly controlled intracellular signaling events that, in many cell types, induce the activation of cysteine proteases known as caspases. The caspase family consists of at least 14 homologs (Alnemri et al., 1996; Humke et al., 1998; Wang et al., 1998), all of which exist in cells as zymogens and require proteolytic cleav-

\footnotetext{
Received Feb. 3, 1999; revised May 5, 1999; accepted May 26, 1999.

This work was supported by Korea Science and Engineering Foundation (KOSEF) Grant 981-0714-100-2 (Y.M.K.), National Institutes of Health Grant R01-GM-44100 (T.R.B.), a Chung-Ang University Special Research grant (H.Y.Y), and National Institutes of Health grant R01-GM-37753 (R.L.S.). J.L. was supported in part by National Institutes of Health Individual National Research Service Award F32-GM-19866.

Correspondence should be addressed to Dr. Young-Myeong Kim, Department of Molecular and Cellular Biochemistry, School of Medicine, Kangwon National University, Kangwon-do, Korea or Dr. Timothy R. Billiar, Department of Surgery, University of Pittsburgh, A1010 Presbyterian-University Hospital, 200 Lothrop Street, Pittsburgh PA 15213.

Copyright (C) 1999 Society for Neuroscience 0270-6474/99/196740-08\$05.00/0
}

age for activation. Autoactivation of caspase- 8 is thought to follow the interaction of procaspase- 8 with the death-inducing signaling complex of the Fas and TNF $\alpha$ receptor (Boldin et al., 1996; Muzio et al., 1996). Caspase-9 is activated when cytochrome $\mathrm{c}$ is released from the mitochondria and binds with Apaf-1 and dATP (P. Li et al., 1997). Sequential activation of other caspases may then follow where caspase- 8 and caspase- 9 cleave/activate caspase-3. Caspase-3 cleaves terminal death substrates leading to the systematic destruction of the cell. Thus, interruption of caspase activation or prevention of cytochrome $\mathrm{c}$ release are potential mechanisms for the prevention of apoptosis.

Neuronal apoptosis is required for normal development of the nervous system but also occurs during pathological states (Narayanan, 1997). Extensive neuronal cell death is observed after acute brain injury, including stroke (Hill et al., 1995) and trauma (Crowe et al., 1997), and is thought to contribute to neurodegenerative diseases, such as Parkinson's disease and Alzheimer's disease (Pettmann and Henderson, 1998). Neuronal apoptosis is directly linked to activation of caspase proteases (Du et al., 1997; Green, 1998; Li et al., 1998; Yoshimura et al., 1998). Caspase-3and caspase-9-deficient mice exhibit increased brain size associated with decreased apoptosis (Kuida et al., 1996; Hakem et al., 
1998). Caspase-3-like protease inhibitors block apoptotic cell death of cultured neurons in response to several stimuli, including trophic factor deprivation (Li et al., 1998) and serum deprivation (Tanabe et al., 1998). The anti-apoptotic proto-oncogene Bcl-2 protects neurons from apoptotic cell death (Park et al., 1996), and $\mathrm{Bcl}-2$ can prevent caspase activation by suppressing cytochrome $\mathrm{c}$ release from mitochondria (Yang et al., 1997). The expression of Bcl-2 decreases to an undetectable level with age (Chen et al., 1997). In adults, it is not well understood how endogenous inhibitors of apoptosis relate to the caspase signaling cascade and regulate programmed neuronal death.

Nitric oxide (NO) is synthesized from L-arginine by one of three isotypes of NO synthase (NOS) and is an endogenous inhibitor of apoptosis in many cell types. NO synthesized by neuronal NOS (nNOS) functions as a synaptic signaling molecule in the nervous system (Bredt and Snyder, 1992) but can lead to neuronal cell death when produced in excess (Dawson et al., 1991; Zhang et al., 1994; Heneka et al., 1998). Cytotoxicity is associated with activation of poly(ADP-ribose) polymerase (PARP) (Zhang et al., 1994) and the formation of highly reactive peroxynitrite by the reaction with superoxide (Beckman et al., 1990). Peroxynitrite can lead to apoptosis in the motor neurons (Estevez et al., 1998a) and PC12 pheochromocytoma cells (Estevez et al., 1995) or necrosis in cortical neurons (Bonfoco et al., 1995). These observations are contrasted by observations showing that NO donors (Farinelli et al., 1996) or NO produced by constitutive nNOS (Estevez et al., 1998b) limit apoptosis induced by trophic factor deprivation in primary neurons and PC12 cells. These reports concluded that the protective actions were mediated by NO activation of soluble guanylyl cyclase. NO can limit apoptosis, however, by direct inhibition of caspase activity by $S$-nitrosylation (Kim et al., 1997b; J. Li et al., 1997), as well as through cGMPdependent mechanisms (Kim et al., 1997b). The role of $S$-nitrosylation of caspases and the mechanism of the cGMPdependent interruption of apoptosis signaling in neuronal cells are not known. Studies were undertaken here to address these two issues using undifferentiated PC12 cells induced to undergo apoptosis by growth factor withdrawal. Our data show that NO inhibits apoptotic death in PC12 cells primarily through a cGMPdependent prevention of caspase-3 activation and mitochondrial cytochrome $\mathrm{c}$ release with minimal contribution from the $S$-nitrosylation of caspases.

\section{MATERIALS AND METHODS}

Materials. RPMI 1640, penicillin, streptomycin, and L-glutamate were purchase from Life Technologies (Gaithersburg, MD). Cytochrome c antibody was obtained from PharMingen (San Diego, CA) and PARP antibody was purchased from Santa Cruz Biotechnology (Santa Cruz, CA). Polyclonal caspase-3 antibody was obtained from Transduction Laboratories (Lexington, KY). $N$-acetyl-Tyr-Val-Ala-Asp- $P$-nitroanilide (AcYVAD-pNA), $N$-acetyl-Asp-Glu-Val-Asp- $P$-nitroanilide (Ac-DEVDpNA), $N$-acetyl-Tyr-Val-Ala-Asp-aldehyde (Ac-YVAD-cho), and AcAsp-Glu-Val-Asp-aldehyde (Ac-DEVD-cho) were obtained from Alexis Corporation (San Diego, CA). $S$-Nitroso- $N$-acetyl-D,L-penicillamine (SNAP) was synthesized, as described previously (Kim et al., 1995b). Diethylenetriamine/NO adduct (DETA/NO) was purchased from Research Biochemicals (Natick, MA). KT5823 was obtained from Calbiochem (San Diego, CA), and 1-H-oxodiazol-[1,2,4]-[4,3-a] quinoxaline-1one (ODQ) was purchased from Promega (Madison, WI). All other reagents were purchased from Sigma (St. Louis, MO), unless indicated otherwise.

Cell culture. Culture dishes were coated by spreading collagen solution [bovine skin collagen $(100 \mathrm{~g} / 250 \mu \mathrm{l}$ in distilled water $)$ ] as a film over the dish and allowed to dry at room temperature in a sterile laminar flow hood. Undifferentiated PC12 cells were initially cultured on the plates and maintained in RPMI 1640 medium containing 10\% horse serum and
$5 \%$ fetal bovine serum supplemented with $2 \mathrm{~mm}$ glutamine, 100 units $/ \mathrm{ml}$ penicillin, and $100 \mu \mathrm{g} / \mathrm{ml}$ streptomycin at $37^{\circ} \mathrm{C}$ with $95 \%$ air $-5 \% \mathrm{CO}_{2}$. PC12 cells were differentiated by treating with NGF $(50 \mathrm{ng} / \mathrm{ml})$ in RPMI 1640 containing $1 \%$ horse serum for $7 \mathrm{~d}$.

Cell viability assay. PC12 cells were washed extensively with serum-free RPMI 1640 medium (three times on the dish followed by four cycles of centrifugation) and replated onto collagen-coated 24-well plates at a density of $2 \times 10^{5}$ cells per well in a volume of $1 \mathrm{ml}$. Cells were treated with NO donors in serum-free RPMI 1640 media for $24 \mathrm{hr}$. For NGF deprivation experiments, the cells were switched to serum-free RPMI 1640 with or without NO donors or 8- bromoadenosine-cGMP (8-BrcGMP) for $72 \mathrm{hr}$. For determination of cell viability, cells were removed from the cell debris by centrifugation at $500 \times g$ for $5 \mathrm{~min}$. The supernatant containing cell debris was discarded, and the cell pellet was resuspended in $0.25 \mathrm{ml}$ of the solution $\left(0.5 \%\right.$ Triton $\mathrm{X}-100,2 \mathrm{mM} \mathrm{MgCl} \mathrm{M}_{2}$,

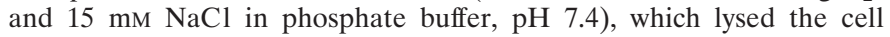
membrane but left the nuclei intact (Soto and Sonnenschein, 1985). The nuclei were counted in a hematocytometer. In this assay, nuclei of dead cells generally disintegrate or appear pyknotic and are irregularly shaped when undergoing apoptosis. In contrast, nuclei of living cells are bright under phase contrast and have clearly defined membranes. Counts were performed on triplicate wells.

Assay of DEVDase activity. The cell pellets were washed with ice-cold PBS and resuspended in $100 \mathrm{~mm}$ HEPES buffer, pH 7.4, containing protease inhibitors $(5 \mathrm{mg} / \mathrm{ml}$ aprotinin and pepstatin, $10 \mathrm{mg} / \mathrm{ml}$ leupeptin, and $0.5 \mathrm{~mm}$ phenylmethylsulfonyl fluoride). The cell suspension was lysed by three freeze-thaw cycles, and the cytosolic fraction (S100) was obtained by centrifugation at $100,000 \times g$ for $1 \mathrm{hr}$ at $4^{\circ} \mathrm{C}$. DEVDase activity was assayed by measuring the increased absorbance at $405 \mathrm{~nm}$ after cleavage of $200 \mu \mathrm{M}$ Ac-DEVD-pNA (Kim et al., 1997b). The enzyme activity was calculated from a standard curve prepared using $p$-nitroanaline.

DNA fragmentation. Cytosolic DNA was prepared according to the method of Leist et al. (1995). Briefly, cell pellets were resuspended in 750 $\mu \mathrm{l}$ of lysis buffer $(20 \mathrm{~mm}$ Tris-HCl, $10 \mathrm{~mm}$ EDTA, and $0.5 \%$ Triton $\mathrm{X}-100, \mathrm{pH} 8.0$ ) and occasionally shaken while on ice for $45 \mathrm{~min}$. DNA was extracted with phenol and precipitated with alcohol. The pellet was dried and resuspended in $100 \mathrm{ml}$ of $20 \mathrm{~mm}$ Tris- $\mathrm{HCl}, \mathrm{pH} 8.0$. After digesting RNA with RNase $(0.1 \mathrm{mg} / \mathrm{ml})$ at $37^{\circ} \mathrm{C}$ for $1 \mathrm{hr}$, samples $(15 \mu \mathrm{l})$ were electrophoresed through a $1.2 \%$ agarose gel in $450 \mathrm{~mm}$ Tris borateEDTA buffer, $\mathrm{pH}$ 8.0. DNA was photographed under visualization with UV light.

Western blot analysis. Cell pellets were suspended in ice-cold sterilized water and kept on ice for $1 \mathrm{~min}$. The suspension was mixed with a $500 \mathrm{~mm}$ sucrose solution and carefully homogenized in a Dounce tissue grinder with a loose pestle. Cytosols were obtained by centrifugation at $100,000 \times g$ for $1 \mathrm{hr}$. Cytosolic proteins $(40 \mu \mathrm{g})$ were separated on SDS-PAGE and transferred onto a nitrocellulose membrane. For Western blot of PARP and caspase-3, cells $\left(2 \times 10^{5}\right.$ cells $)$ were mixed with an equal volume of $2 \times$ SDS-sample buffer and then lysed on ice by ultrasonicator with microtip. Proteins were separated on $8 \%$ SDS-PAGE for PARP and $12 \%$ SDS-PAGE for caspase- 3 and then transferred to nitrocellulose. The membranes were hybridized with cytochrome c antibody (1:1000), caspase-3 antibody (1:500), or PARP antibody (1:500), and protein bands were visualized by exposing to x-ray film, as described previously(Kim et al., 1997a).

Other analysis. Protein concentration was determined with the BCA assay (Pierce, Rockford IL). Data are presented as means \pm SD of at least three separated experiments, except where results of blots are shown, in which case a representative experiment is depicted in the figures. Comparisons between two values were analyzed using Student's $t$ test. Differences were considered significant when $p \leq 0.05$.

\section{RESULTS \\ NO inhibition of PC12 cell apoptosis is concentration-dependent}

NO has been shown previously to delay apoptotic death in PC12 cells (Farinelli et al., 1996). Consistent with these previous observations, we found that the NO donor SNAP prevented PC12 cell death caused by serum deprivation in a dose-dependent manner up to $100 \mu \mathrm{M}$ SNAP, but that a higher dose decreased cell viability (Fig. 1). Since trophic factor deprivation induces neuronal apoptosis by activating the caspase cascade (Stefanis et al., 


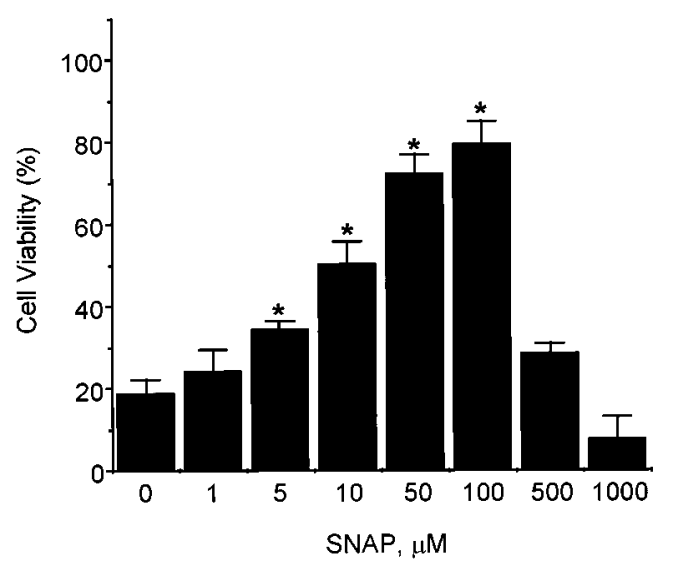

Figure 1. Cytoprotective effects of SNAP on the survival of PC12 cells in serum-free conditions. Cells were collected, washed extensively with serum-free RPMI 1640 medium, and replated onto collagen-coated 24well plates at a density of $2.5 \times 10^{5}$ cells per well in a volume of $1 \mathrm{ml}$ of serum-free media. Cells were treated with the same concentration of the NO donor SNAP. At $24 \mathrm{hr}$, cell viability was determined by counting intact nuclei after lysing of the cell membrane (mean \pm SD. $n=3$ ). ${ }^{*} p<$ 0.01 versus nonpretreatment.

1996; Li et al., 1998), we examined the effect of SNAP and inhibitors of caspase family proteases on PC12 cell apoptosis and caspase activity. The caspase-3-like protease inhibitor AcDEVD-cho prevented serum deprivation-induced PC12 cell death, whereas the caspase-1-like protease inhibitor Ac-YVADcho did not (Fig. 2A). The cytoprotective effect of Ac-DEVD-cho was comparable with the effect of SNAP $(100 \mu \mathrm{M})$ treatment. Caspase-1- and caspase-3-like enzyme activities were measured in the cytosol from serum-deprived PC12 cells by a colorimetric assay using substrate-specific tetrapeptides (Fig. 2B). YVADAase (caspase-1-like protease) activity in serum-deprived PC12 cells was comparable with that measured in PC12 cells cultured in serum-supplemented media. YVADase activity was not detectable in membrane fraction (data not shown). However, DEVDase activity in serum-deprived PC12 cell extracts was 10-fold higher than that of control PC12 cells. The increase in DEVDase activity was unchanged by the addition of Ac-YVAD-cho but decreased by Ac-DEVD-cho or SNAP. Another NO donor, DETA/NO $(100 \mu \mathrm{M})$, showed a similar protective effect on cell viability and caspase activity (data not shown). These results indicate that the cytoprotective effect of NO on serum-deprived PC12 cells may be caused by an inhibition of DEVDase protease activation and/or activity.

\section{Anti-apoptotic actions of NO and cGMP production}

The anti-apoptotic actions of NO in PC12 cells (Farinelli et al., 1996) and primary cultures of motor and sympathetic neurons (Farinelli et al., 1996; Estevez et al., 1998b) have been shown to involve cGMP. To confirm the role of cGMP in NO-mediated protection and to determine the effects of cGMP on caspase activity, the effects of SNAP on PC12 cells were examined in the presence of the specific inhibitor of soluble guanylyl cyclase ODQ (Fig. 3). ODQ did not affect the cell viability of serumsupplemented cells but inhibited the protective effect of SNAP on serum-deprived cells (Fig. $3 A$ ). DNA fragmentation typical of apoptosis was identified in serum-deprived PC12 cells (Fig. $3 B$ ). SNAP prevented DNA fragmentation, and ODQ significantly blocked this effect of SNAP. Treatment with ODQ also prevented the capacity of SNAP to suppress DEVDase activity (Fig. 3C).
The reducing agent dithiothreitol (DTT) can reactivate DEVDase proteases inactivated by $S$-nitrosylation (Kim et al., 1997b). However, incubation of lysate from SNAP-treated PC12 cells with DTT caused only a small increase in DEVDase activity (Fig. 3C), suggesting that SNAP exposure did not result in the inhibition of DEVDase activity by $S$-nitrosylation.

One of the established substrates for caspase-3 protease in cells is PARP, which is cleaved from $116 \mathrm{kDa}$ intact protein into 85 and $31 \mathrm{kDa}$ fragments during apoptosis (Nicholson et al., 1995). The cleaved product $(85 \mathrm{kDa})$ of PARP was detected in the lysate of serum-deprived PC12 cells by Western blot. PARP cleavage was almost completely inhibited by SNAP treatment, and this inhibition was primarily reversed by the addition of ODQ (Fig. 3D). Together, these findings indicate that a major effector for NOmediated inhibition of PC12 cell apoptosis is cGMP, which inhibits the activation of DEVDase proteases.

\section{cGMP-mediated protective actions involve cGMP- dependent protein kinase activation}

Many actions of cGMP are the result of the activation of cGMPdependent protein kinase or protein kinase G. Therefore, we used the protein kinase $\mathrm{G}$ inhibitor KT5823 to determine whether the protective actions of cGMP were mediated by the activation of protein kinase G. The cell-permeable cGMP analog 8-BrcGMP protected PC12 cells from serum-deprived apoptosis in a concentration-dependent manner. This protection was significantly inhibited by the addition of KT5823 but not by ODQ (Fig. $4 A$ ). Treatment with 8 -Br-cGMP almost completely inhibited DEVDase activity in the serum-deprived PC12 cells, and this inhibition was reversed, in part, by KT5823 but not ODQ (Fig. $4 B$ ). Furthermore, DEVDase activity was not increased by preincubating the cell lysate with DTT. Another cGMP analog, dibutyl cGMP, exhibited the same effect on cell viability and DEVDase activity (data not shown). These results indicate that the effects of cGMP on the activation of DEVDase enzymes are mediated, at least in part, via the activation of protein kinase $\mathrm{G}$.

\section{cGMP prevents cytochrome c release and DEVDase activation}

Cytochrome c release from mitochondria can either be a consequence of caspase-3 activation (Kim et al., 1998) or serve to amplify caspase-3 activation by forming an "apoptosome" composed of cytochrome c, Apaf-1, dATP, and procaspase-9 (P. Li et al., 1997). The complex activates caspase-9, which then processes and activates other caspases, including caspase-3. To investigate the effects of NO and cGMP on cytochrome c release, we measured the cytosolic level of cytochrome $\mathrm{c}$ by Western blot analysis (Fig. 5A). Cytochrome c release was increased by serum deprivation, and the increase was suppressed by addition of SNAP or 8-Br-cGMP. The suppressive effects of these compounds were partially reversed by ODQ and KT5823, respectively. To determine whether caspase-3 was specifically activated, Western blot analysis was performed to identify the cleaved active fragment (p17) of caspase-3. As shown in Figure 5B, caspase-3 was activated by serum deprivation, and the activation was suppressed by addition of SNAP and 8-Br-cGMP. This suppression was also prevented by ODQ and KT5823, respectively. These results indicate that the anti-apoptotic effect of NO is associated with inhibition of mitochondrial cytochrome c release and an inhibition of caspase- 3 activation through cGMP production and activation of protein kinase $\mathrm{G}$. 
A

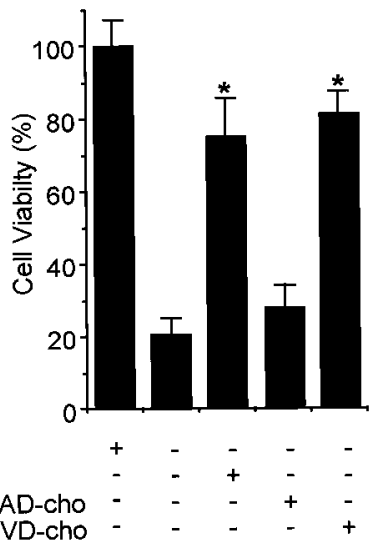

B

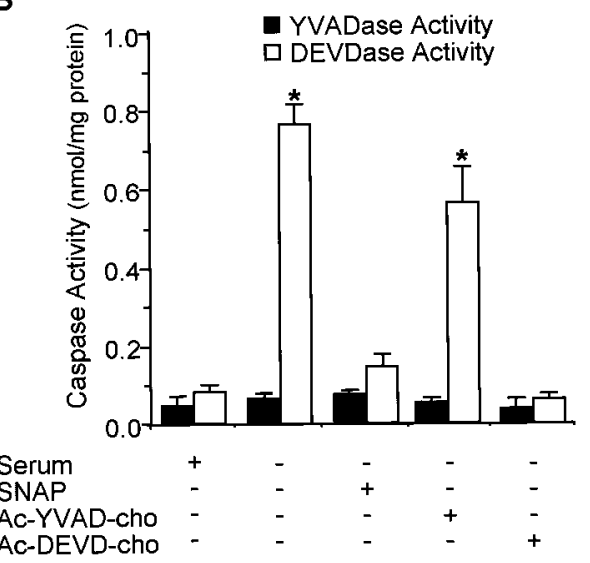

Figure 2. Cytoprotective effects of SNAP and caspase inhibitors on survival of PC12 cells in serumfree media. Cells were treated with SNAP $(100 \mu \mathrm{M})$, Ac-YVAD-cho $(200 \mu \mathrm{M})$, or Ac-DEVD-cho (200 $\mu \mathrm{M})$ in serum-free media. At $24 \mathrm{hr}$, cell viability was determined by counting intact nuclei (mean \pm SD; $n=4)$. PC12 cells were collected, washed with ice-cold PBS, and lysed in $100 \mathrm{~mm}$ HEPES buffer, $\mathrm{pH} 7.4$, containing protease inhibitors. The cytosolic fraction was obtained by centrif ugation at $100,000 \times$ $g$ for $30 \mathrm{~min}$ at $4^{\circ} \mathrm{C}$. Caspase enzyme activity was measured with Ac-YVAD-pNA for caspase-1-like activity (or YVADase) and Ac-DEVD-pNA for caspase-3-like activity (or DEVDase) in a colorimetric assay (mean $\pm \mathrm{SD} ; n=3$ ). ${ }^{*} p<0.01$ versus nonpretreatment.

\section{nNOS gene transfer inhibits apoptosis and cytochrome c release}

To determine the capacity of endogenous NO to inhibit PC12 cell apoptosis, we stably transfected PC12 cells with the nNOS cDNA and examined the effect of nNOS-produced $\mathrm{NO}$ on serum deprivation-induced PC12 cell death. Cells expressing nNOS produced $38 \pm 4 \mathrm{nmol}$ of $\mathrm{NO}_{2}^{-} / \mathrm{mg}$ protein $/ 24 \mathrm{hr}$ compared with $6 \pm 2 \mathrm{nmol}$ of $\mathrm{NO}_{2}{ }^{-} / \mathrm{mg}$ protein $/ 24 \mathrm{hr}$ in control transfectant. nNOS-containing PC12 cells did not die in response to serum deprivation nor was cytochrome $\mathrm{c}$ detected in the cytosol. Cells stably transfected with $\beta$-galactosidase cDNA were not protected (Fig. 6). The inhibition of cytochrome c release, as well as the decreases in DEVDase activity in nNOS-containing PC12 cells, were both prevented by treatment with ODQ or KT5823 and the NOS inhibitor NMA.

\section{NO and cGMP protect differentiated PC12 cells from NGF deprivation-induced apoptosis}

To investigate the possible role of $\mathrm{NO} \rightarrow \mathrm{cGMP}$ pathway in survival of postmitotic PC12 neurons, we differentiated PC12 cells by treatment with NGF for $7 \mathrm{~d}$ and then examined the effect of NO and cGMP on apoptosis induced by NGF withdrawal. The NO donors DETA/NO and SNAP, as well as 8-Br-cGMP, protected the differentiated PC12 cells from NGF deprivation-induced apoptosis (Fig. 7A). DEV Dase activity was increased in differentiated PC12 cells by NGF withdrawal, and the increased activity was suppressed by the addition of SNAP, DETA/NO, or 8-BrcGMP (Fig. 7B). These data suggest that NO may function as a regulator of neuronal cell death in development, as well as in pathological conditions.

\section{DISCUSSION}

This study was undertaken to determine whether $S$-nitrosylation of caspases play a significant role in the anti-apoptotic actions of NO in undifferentiated and differentiated PC12 cells and to determine how NO-induced cGMP production prevents apoptosis in these cells. We showed that concentrations of $\mathrm{NO}$ adequate to activate soluble guanylyl cyclase protect PC12 cells from apoptotic death via a cGMP-dependent mechanism involving the acti-
A

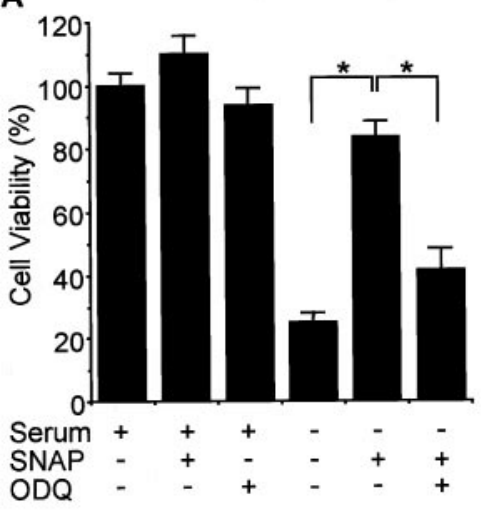

C

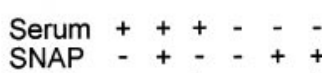

ODQ --+--+

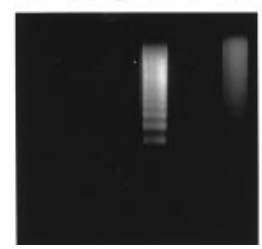

B

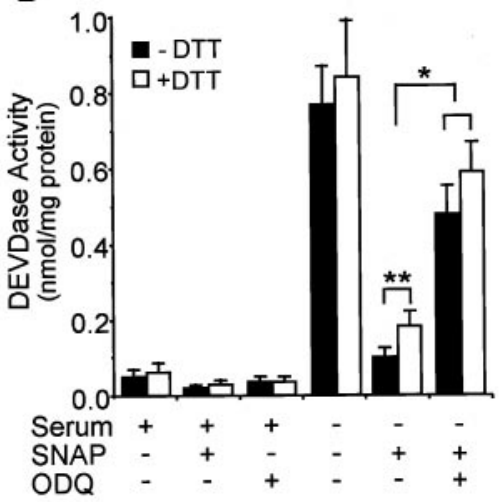

D

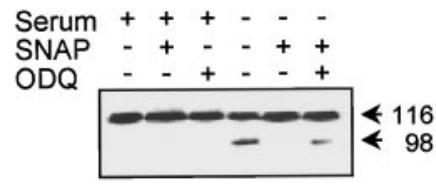

Figure 3. A guanylyl cyclase inhibitor reversed the cytoprotective effect of SNAP on serum-deprived PC12 cells. Cells were treated with SNAP $(100 \mu \mathrm{M})$ plus ODQ $(40 \mu \mathrm{M})$ in the presence and absence of serum. Cell viability $(A)$, DEV Dase activity $(B)$, DNA fragmentation $(C)$, and PARP fragmentation $(D)$ were determined as described in Materials and Methods. Data represent mean $\pm \mathrm{SD}$ of three experiments. $* p<0.01 ; * * p<0.05$. 
A

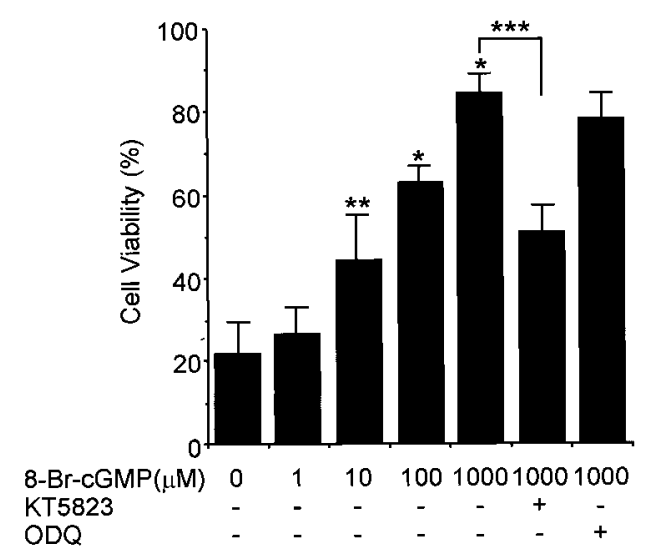

B

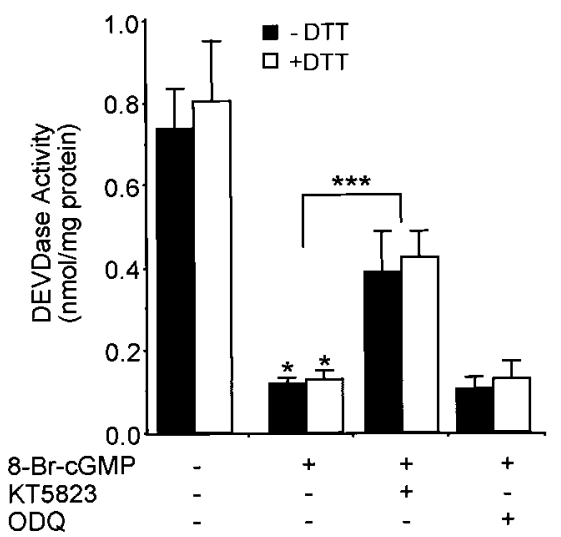

Figure 4. A protein kinase $\mathrm{G}$ inhibitor reverses the cGMP-dependent protection of serum-deprived apoptosis of PC12 cells. Cells were cultured in serum-free media containing different concentrations of $8-\mathrm{Br}$ cGMP $(A)$ or $100 \mu \mathrm{M} 8$-Br-cGMP $(B)$ with or without KT5823 (180 nM) or ODQ (40 $\mu \mathrm{M}) . A$, Cell viability was measured by counting intact nuclei (mean $\pm \mathrm{SD} ; n=3$ ). $B$, DEVDase activity was determined by a colorimetric assay using Ac-DEVD-pNA after incubation of lysate with or without $20 \mathrm{~mm}$ DTT for 30 min (mean $\pm \mathrm{SD} ; n=3$ ). Similar results were obtained by addition of dibutylcGMP into PC12 cell culture. ${ }^{*} p<0.01$ versus nontreatment; ${ }^{* *} p<0.05$ versus nontreatment; ${ }^{* *} p<0.01$. vation of protein kinase G. Although NO can suppress apoptosis by direct inhibition of caspase activity, this does not appear to occur in PC12 cells. Instead, the $\mathrm{NO} \rightarrow$ cGMP $\rightarrow$ protein kinase $\mathrm{G}$ pathway inhibits caspase- 3 activation and prevents mitochondrial cytochrome $\mathrm{c}$ release. Thus, these results identify a key interaction between $\mathrm{NO}$ and $\mathrm{cGMP} / \mathrm{G}$ kinase with the caspase cascade in PC12 cells and provide a molecular basis for the inhibition of apoptosis by NO in a neuronal cell type.

The role of NO in the regulation of apoptosis is complex because NO induces apoptosis in some cell types but prevents apoptosis in others. In neurons, NO can either induce (Heneka et al., 1998) or prevent (Farinelli et al., 1996; Estevez et al., 1998b) apoptosis, depending on the conditions studied (Lipton et al., 1993). In other cell types, the induction of apoptosis often requires exposure to high concentrations of NO donors or expression of high-output inducible NO synthase ( $\mathrm{Lu}$ et al., 1996; Heneka et al., 1998). Cell types shown to be protected from apoptosis by NO are neuronal cells, including PC12 cells (Farinelli et al., 1996), as well as motor and sympathetic neurons (Farinelli et al., 1996; Estevez et al., 1998b), and others such as hepatocytes (Kim et al., 1997a,b), endothelial cells (Dimmeler et al., 1997), human B lymphocytes (Mannick et al., 1994), splenocytes (Genaro et al., 1995), eosinophils (Beauvais et al., 1995), cardiac myocytes (Cheng et al., 1995), and ovarian follicles (Chun et al., 1995). Factors that govern the consequences of NO on cell survival are poorly understood but appear to be related to cell type-specific factors, concentration of NO, and the presence of other free radicals. We have shown that pretreatment with NO protects hepatocytes from apoptotic cell death by induction of heat shock protein 70 (Kim et al., 1997a) and heme oxygenase-1 (Kim et al., 1995a,b). Concurrent NO production can prevent apoptosis by direct inhibition of activity of DEVDase proteases
(Dimmeler et al., 1997; Kim at al., 1997b; Tenneti et al., 1997), prevention of Bcl-2 protein fragmentation and cytochrome $\mathrm{c}$ release (Kim et al., 1998), and the upregulation of anti-apoptotic genes such as Bcl-xL (Okada et al., 1998). These anti-apoptotic processes are independent of cGMP and are thought to be linked to NO-dependent changes of cellular redox states. NO can also stimulate cGMP production, and cGMP has been shown to prevent apoptosis in PC12 cells (Farinelli et al., 1996), motor and sympathetic neurons (Farinelli et al., 1996; Estevez et al., 1998b), B lymphocytes (Genaro et al., 1995), eosinophils (Beauvais et al., 1995), hepatocytes (Kim et al., 1997b), cultured ovarian follicles (Chun et al., 1995), and T lymphocytes (Sciorati et al., 1997). In splenocytes, the cGMP-mediated protection occurs in association with an induction of Bcl-2 mRNA and protein (Genaro et al., 1995). Our studies confirm previous results showing that cGMP protects PC12 cells from apoptosis caused by growth factor deprivation (Farinelli et al., 1996).

The activation of soluble guanylyl cyclase occurs when its heme interacts with a low level of NO ( $\sim 1 \mathrm{nM})$ (Archer, 1993), and NO has been shown to stimulate cGMP production in PC12 cells (Whalin et al., 1991). We show here that the NO donor SNAP protects PC12 cells from apoptosis when added at a concentration between 5 and $100 \mu \mathrm{M}$. Higher concentrations of SNAP no longer protected and even further reduced the viability of serumdeprived cells. SNAP releases NO with a half-life of $\sim 10 \mathrm{hr}$ (Arnelle and Stamler, 1995); therefore, the lower concentration of SNAP used in our experiments probably released NO at levels of intracellular concentrations adequate to activate soluble guanylyl cyclase. Similarly, nNOS-transfected cells were also completely protected. In the absence of agonist, which increases intracellular calcium levels, nNOS produces only small amount of NO. However, the levels of NO produced in nNOS- expressing
Figure 5. SNAP and 8-Br-cGMP prevent mitochondrial cytochrome c release and caspase-3 activation in serum-deprived PC12 cells. Cells were treated with SNAP $(100 \mu \mathrm{M})$, 8-Br-cGMP (1 mM), ODQ $(40 \mu \mathrm{M})$, or KT5823 (180 nM) in serum-free media. After $6 \mathrm{hr}$ for cytochrome c release and $12 \mathrm{hr}$ for caspase-3 activation, cells were harvested and homogenized, and then the cytosolic fraction was prepared by centrif ugation at $100,000 \times g$. Cytochrome $\mathrm{c}$ release $(A)$ and caspase activation $(B)$ were determined by Western blot analysis.
A

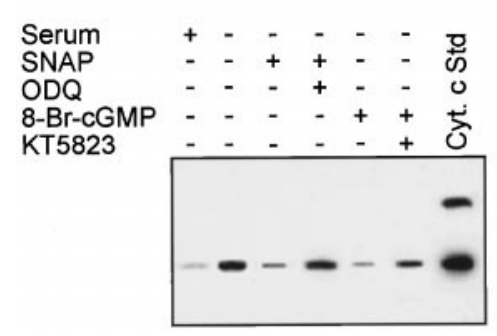

B

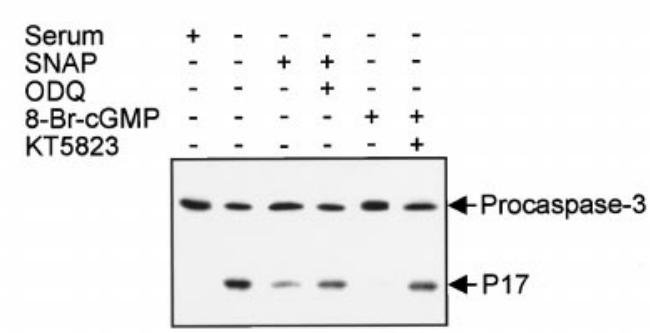


A

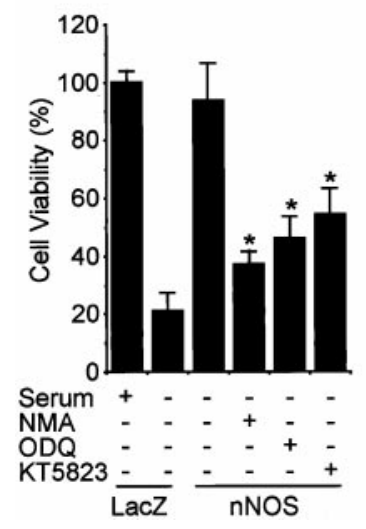

B

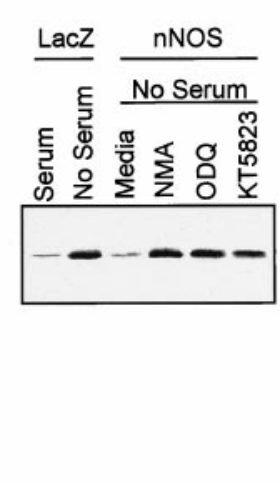

C

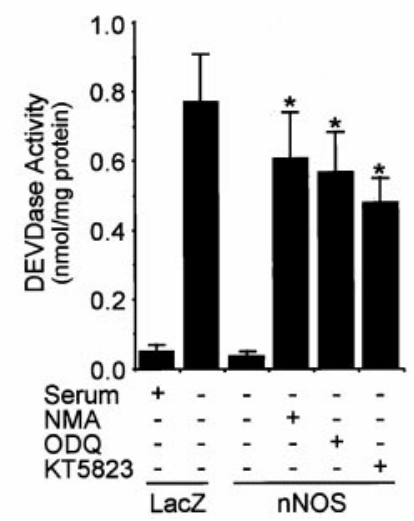

Figure 6. nNOS gene transfer inhibits apoptotic cell death, cytochrome c release, and DEV Dase activity in PC12 cells. Plasmid (pCMV) containing the nNOS or LacZ cDNA was transferred into PC12 cells by the lipofection method. Transfectants were selected using $800 \mu \mathrm{g} / \mathrm{ml}$ G418. Isolated cells were treated with or without NMA (1.5 mM), ODQ (40 $\mu \mathrm{M})$, and KT5823 (180 nM) in serum-free media. $A$, Cell viability was determined by counting intact nuclei (mean $\pm \mathrm{SD} ; n=$ 3). $B$, Cytochrome c release was measured by Western blot. $C$, DEVDase activity was measured by a colorimetric assay using Ac-DEVDpNA (mean $\pm \mathrm{SD} ; n=3) .{ }^{*} p<0.01$ versus nontreatment.
PC12 cells were adequate to prevent apoptosis by a cGMPdependent mechanism.

Evidence that cGMP is an effective neuroprotectant comes from the studies on the secreted forms of Alzheimer's disease (Barger et al., 1995). $\beta$-Amyloid precursor protein was shown to protect cultured hippocampal neurons from glucose deprivation and glutamate toxicity through increases in cGMP levels (Barger et al., 1995). Furthermore, NO donor and cGMP prevented primary hippocampal neurons by activation of $\mathrm{K}^{+}$channels through cGMP-dependent kinase activation (Furukawa et al., 1996). We extended these previous studies by providing a link between cGMP and caspase signaling. cGMP activates protein kinase G (Kim et al., 1997b), and we show that protein kinase G inhibitor KT5823 partially reversed the anti-apoptotic effect of NO and the suppression of DEVDase protease activation by 8-Br-cGMP. These data suggest that protein kinase $\mathrm{G}$ activation by NO/cGMP suppresses apoptotic signaling upstream of caspase activation. We also found that NO and cGMP block mitochondrial cytochrome $\mathrm{c}$ through the activation of protein kinase $\mathrm{G}$. The loss of mitochondrial cytochrome $\mathrm{c}$ decreases the coupling efficiency of the electron transport chain, increasing the production of superoxide (Cai and Jones, 1998). Superoxide has been implicated in the activation of caspase proteases (Peled-Kamar et al., 1998). Cytochrome c release also leads to caspase activation through the interaction of cytochrome $\mathrm{c}$ with Apaf-1 and dATP, resulting in the activation of caspase-9 (P. Li et al., 1997). How serum deprivation leads to DEVDase activation or cytochrome c release in PC12 cells is unknown. One possibility is that the activation of upstream caspases promotes mitochondrial changes leading to cytochrome $\mathrm{c}$ release. Our studies also do not evaluate the mechanism by which cGMP/protein kinase $G$ prevent caspase-3 activation or cytochrome c release. Known substrates for protein kinase $\mathrm{G}$ include inositol $(1,4,5) \mathrm{P}_{3}$ receptor (Ferris and Snyder, 1992), DARPP-32 (Tsou et al., 1993), and cGMP-BPDE (Thomas et al., 1990) in the nervous system. A role for these substrates in the inhibition of apoptosis is not clear. We have preliminary evidence in PC12 cells and hepatocytes that cGMP can activate AKT kinase (our unpublished data). Activation of AKT kinase by cGMP could prevent apoptosis by the phosphorylation of BAD interfering with mitochondrial cytochrome c release (Datta et al., 1997; del Peso et al., 1997) and caspase-9 inhibiting caspase signaling (Cardone et al., 1998).

NO can modify enzyme function by $S$-nitrosylation of protein thiol groups (Stamler, 1994). All caspase enzymes contain a single cysteine residue at the catalytic site. The modification of this amino acid by thiol-reactive agents, including NO reaction products such as $\mathrm{NO}^{+}$, inhibits the catalytic activity of the enzyme. When caspases are inhibited by $S$-nitrosylation, the thiol-bound NO groups can be effectively removed by the reducing agent DTT, thus reactivating the enzyme (Kim et al., 1997b). $S$-Nitrosylation of caspases occurs efficiently in primary hepatocytes (Kim et al., 1997b), endothelial cells (Dimmeler et al., 1997), some tumor cell lines (Mannick et al., 1997), and ironpreloaded MCF7 cells (Kim et al., 1998). Factors that determine the nitrosylating capacity of cells may include the abundance of iron within the cell (Boese et al., 1995) and the presence of
A

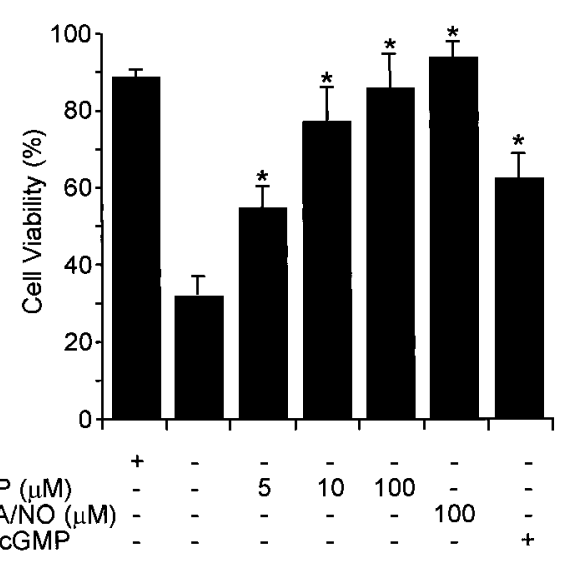

B

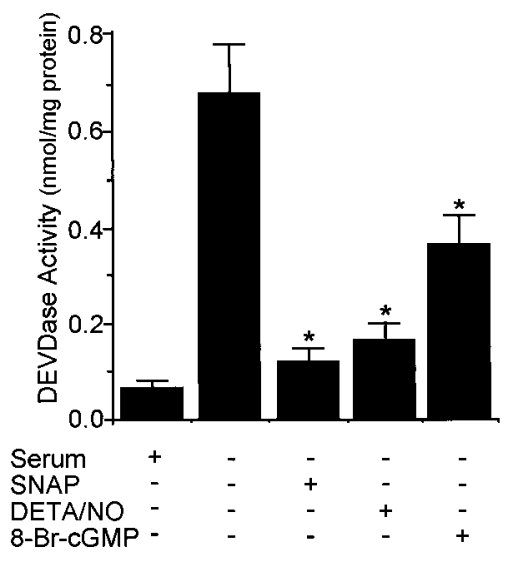

Figure 7. NO donors and 8-Br-cGMP prevent differentiated $\mathrm{PC} 12$ cells from NGF withdrawal-induced apoptosis. PC12 cells were differentiated by treating with NFG (50 ng/ml) in RPMI 1640 medium containing $1 \%$ horse serum for $7 \mathrm{~d}$. The culture media were switched to serum-free media with or without SNAP $(100 \mu \mathrm{M})$, DETA/NO $(100 \mu \mathrm{M})$, or 8-BrcGMP $(1000 \mu \mathrm{M})$, and cell viability $(A)$ and DEVDase activity $(B)$ were measured after 72 and $48 \mathrm{hr}$, respectively. $* p<0.01$ versus nontreatment. 
molecular oxygen (Wink et al., 1993). We found little evidence for $S$-nitrosylation of caspases in PC12 cells. The failure of PC12 cells to carry out $S$-nitrosylation could explain the toxicity of higher levels of NO seen in our experiments.

The present results show that NO protects neuronal PC12 cells from serum deprivation-induced apoptosis by elevation or maintenance of intracellular cGMP. However, production of NO by nNOS and NO-generating compounds can induce apoptotic cell death of motor neurons in trophic factor-deprived conditions (Estevez et al., 1998b) and in PC12 cells with decreased superoxide activity (Troy et al., 1996). In these experiments, the toxicity of NO appears to result from the simultaneous production of NO and superoxide leading to the formation of peroxynitrite. Peroxynitrite is a potent oxidant that can cause direct cellular injury and induce apoptosis (Lin et al., 1995). Thus, the balance between anti-apoptotic and proapoptotic effects of NO in neurons may be dependent on the levels of superoxide anion production. Superoxide anion generation can be increased by cytochrome c release (Cai and Jones, 1998). By inhibiting the NO/cGMP/ protein kinase $\mathrm{G}$ pathway, mitochondrial cytochrome c release could inhibit superoxide anion generation and limit subsequent NO toxicity.

It is thus conceivable that, in addition to serving as a neurotransmitter in neurons, endogenous production of NO may function as a regulator of neuronal apoptosis in development, as well as in pathological conditions. Indeed, we have observed increases in neuronal apoptosis after controlled cortical impact in inducible NOS-deficient animals (our unpublished observations). This injury is associated with a marked increase in caspase activity in the brain. Our studies show that NO-stimulated cGMP production inhibits the caspase signaling cascade via protein kinase G-dependent inhibition of mitochondrial cytochrome c release. The molecular mechanism by which protein kinase $G$ inhibits cytochrome c release is now under investigation.

\section{REFERENCES}

Alnemri ES, Livingston DJ, Nicholson DW, Salvesen G, Thornberry NA, Wong WW, Yuan J (1996) Human ICE/CED-3 protease nomenclature. Cell 87:171.

Archer S (1993) Measurement of nitric oxide in biological models. FASEB J 7:349-360.

Arnelle DR, Stamler JS (1995) $\mathrm{NO}^{+}, \mathrm{NO}$, and $\mathrm{NO}^{-}$donation by Snitrosothiols: implications for regulation of physiological functions by $S$-nitrosylation and acceleration of disulfide formation. Arch Biochem Biophys 18:279-285.

Barger SW, Fiscus RR, Ruth P, Hofmann F, Mattson MP (1995) Role of cyclic GMP in the regulation of neuronal calcium and survival by secreted forms of $\beta$-amyloid precursor. J Neurochem 64:2087-2096.

Beauvais F, Michel L, Dubertret L (1995) The nitric oxide donors, azide and hydroxylamine, inhibit the programmed cell death of cytokinedeprived human eosinophils. FEBS Lett 361:229-232.

Beckman JS, Beckman TW, Chen J, Marshall PA, Freeman BA (1990) Apparent hydroxyl radical production by peroxynitrite: implications for endothelial injury from nitric oxide and superoxide. Proc Natl Acad Sci USA 87:1620-1624.

Boese M, Mordvintcev PI, Vanin AF, Busse R, Mulsch A (1995) $S$-Nitrosation of serum albumin by dinitrosyl-iron complex. J Biol Chem 270:29244-29249.

Boldin MP, Goncharov TM, Goltsev YV, Wallach D (1996) Involvement of MACH, a novel MORT1/FADD-interacting protease, in Fas/ APO-1- and TNF receptor-induced cell death. Cell 85:803-815.

Bonfoco E, Krainc D, Ankarcrona M, Nicotera P, Lipton SA (1995) Apoptosis and necrosis: two distinct events induced, respectively, by mild and intense insults with $N$-methyl-D-aspartate or nitric oxide/ superoxide in cortical cell cultures. Proc Natl Acad Sci USA 92:7162-7166.

Bredt DS, Snyder SH (1992) Nitric oxide, a novel neuronal messenger. Neuron 8:3-11.
Cai J, Jones DP (1998) Superoxide in apoptosis. Mitochondrial generation triggered by cytochrome c loss. J Biol Chem 273:11401-11404.

Cardone MH, Roy N, Stennicke HR, Salvesen GS, Franke TF, Stanbridge E, Frisch S, Reed JC (1998) Regulation of cell death protease caspase- 9 by phosphorylation. Science 282:1318-1321.

Chen DF, Schneider GE, Martinou JC, Tonegawa S (1997) Bcl-2 promotes regeneration of severed axons in mammalian CNS. Nature 385:434-439.

Cheng W, Li B, Kajstura J, Li P, Wolin MS, Sonnenblick EH, Hintze TH, Olivetti G, Anversa P (1995) Stretch-induced programmed myocyte cell death. J Clin Invest 96:2247-2259.

Chun SY, Eisenhauer KM, Kubo M, Hsueh AJ (1995) Interleukin-1 $\beta$ suppresses apoptosis in rat ovarian follicles by increasing nitric oxide production. Endocrinology 136:3120-3127.

Crowe MJ, Bresnahan JC, Shuman SL, Masters JN, Beattie MS (1997) Apoptosis and delayed degeneration after spinal cord injury in rats and monkeys. Nat Med 3:73-76.

Datta SR, Dudek H, Tao X, Masters S, Fu H, Gotoh Y, Greenberg ME (1997) Akt phosphorylation of BAD couples survival signals to the cell-intrinsic death machinery. Cell 91:231-241.

Dawson VL, Dawson TM, London ED, Bredt DS, Snyder SH (1991) Nitric oxide mediates glutamate neurotoxicity in primary cortical cultures. Proc Natl Acad Sci USA 88:6368-6371.

del Peso L, Gonzalez-Garcia M, Page C, Herrera R, Nunez G (1997) Interleukin-3-induced phosphorylation of BAD through the protein kinase Akt. Science 278:687-689.

Delaney CA, Tyrberg B, Bouwens L, Vaghef H, Hellman B, Eizirik DL (1996) Sensitivity of human pancreatic islets to peroxynitrite-induced cell dysfunction and death. FEBS Lett 394:300-306.

Dimmeler S, Haendeler J, Nehls M, Zeiher AM (1997) Suppression of apoptosis by nitric oxide via inhibition of interleukin-1- $\beta$-converting enzyme (ICE)-like and cysteine protease protein (CPP)-32-like proteases. J Exp Med 185:601-607.

Du Y, Bales KR, Dodel RC, Hamilton-Byrd E, Horn JW, Czilli DL, Simmons LK, Ni B, Paul SM (1997) Activation of a caspase 3-related cysteine protease is required for glutamate-mediated apoptosis of cultured cerebellar granule neurons. Proc Natl Acad Sci USA 94:11657-11662.

Estevez AG, Radi R, Barbeito L, Shin JT, Thompson JA, Beckman JS (1995) Peroxynitrite-induced cytotoxicity in PC12 cells: evidence for an apoptotic mechanism differentially modulated by neurotrophic factors. J Neurochem 65:1543-1550.

Estevez AG, Spear N, Manuel SM, Radi R, Henderson CE, Barbeito L, Beckman JS (1998a) Nitric oxide and superoxide contribute to motor neuron apoptosis induced by trophic factor deprivation. J Neurosci 18:923-931.

Estevez AG, Spear N, Thompson JA, Cornwell TL, Radi R, Barbeito L, Beckman JS (1998b) Nitric oxide-dependent production of cGMP supports the survival of rat embryonic motor neurons cultured with brain-derived neurotrophic factor. J Neurosci 18:3708-3714.

Farinelli SE, Park DS, Greene LA (1996) Nitric oxide delays the death of trophic factor-deprived PC12 cells and sympathetic neurons by a cGMP-mediated mechanism. J Neurosci 16:2325-2334.

Ferris CD, Snyder SH (1992) Inositol 1,4,5-triphosphate-activated calcium channels. Annu Rev Physiol 54:469-488.

Furukawa K, Barger SW, Blalock EM, Mattson MO (1996) Activation of $\mathrm{K}^{+}$channels and suppression of neuronal activity by secreted $\beta$-amyloid-precusor protein. Nature 379:74-78.

Genaro AM, Hortelano S, Alvarez A, Martinez C, Bosca L (1995) Splenic B lymphocyte programmed cell death is prevented by nitric oxide release through mechanisms involving sustained Bcl-2 levels. J Clin Invest 95:1884-1890.

Green DR (1998) Apoptotic pathways: the roads to ruin. Cell 94:695-698.

Hakem R, Hakem A, Duncan GS, Henderson JT, Woo M, Soengas MS, Elia A, de la Pompa JL, Kagi D, Khoo W, Potter J, Yoshida R, Kaufman SA, Lowe SW, Penninger JM, Mak TW (1998) Differential requirement for caspase 9 in apoptotic pathways in vivo. Cell 94:339-352.

Heneka MT, Loschmann PA, Gleichmann M, Weller M, Schulz JB, Wullner U, Klockgether T (1998) Induction of nitric oxide synthase and nitric oxide-mediated apoptosis in neuronal PC12 cells after stimulation with tumor necrosis factor- $\alpha /$ lipopolysaccharide. J Neurochem 71:88-94.

Hill IE, MacManus JP, Rasquinha I, Tuor UI (1995) DNA fragmenta- 
tion indicative of apoptosis following unilateral cerebral hypoxiaischemia in the neonatal rat. Brain Res 676:398-403.

Humke EW, Ni J, Dixit VM (1998) ERICE, a novel FLICE-activatable caspase. J Biol Chem 273:15702-15707.

Kim YM, Bergonia H, Lancaster Jr JR (1995a) Nitrogen oxide-induced autoprotection in isolated rat hepatocytes. FEBS Lett 374:228-232.

Kim YM, Bergonia HA, Muller C, Pitt BR, Watkins WD, Lancaster Jr JR (1995b) Loss and degradation of enzyme-bound heme induced by cellular nitric oxide synthesis. J Biol Chem 270:5710-5713.

Kim YM, de Vera ME, Watkins SC, Billiar TR (1997a) Nitric oxide protects cultured rat hepatocytes from tumor necrosis factor- $\alpha$-induced apoptosis by inducing heat shock protein 70 expression. J Biol Chem 272:1402-1411.

Kim YM, Talanian RV, Billiar TR (1997b) Nitric oxide inhibits apoptosis by preventing increases in caspase-3-like activity via two distinct mechanisms. J Biol Chem 272:31138-31148.

Kim YM, Kim TH, Seol DW, Talanian RT, Billiar TR (1998) Nitric oxide suppression of apoptosis occurs in association with an inhibition of $\mathrm{Bcl}-2$ cleavage and cytochrome $\mathrm{c}$ release. J Biol Chem 273:31437-31441.

Krohn AJ, Preis E, Prehn JH (1998) Staurosporine-induced apoptosis of cultured rat hippocampal neurons involves caspase-1-like proteases as upstream initiators and increased production of superoxide as a main downstream effector. J Neurosci 18:8186-8197.

Kuida K, Zheng TS, Na S, Kuan C, Yang D, Karasuyama H, Rakic P, Flavell RA (1996) Decreased apoptosis in the brain and premature lethality in CPP32-deficient mice. Nature 384:368-372.

Leist M, Gantner F, Bohlinger I, Tiegs G, Germann PG, Wendel A (1995) Tumor necrosis factor-induced hepatocyte apoptosis precedes liver failure in experimental murine shock models. Am J Pathol 146:1220-1234.

Li J, Billiar TR, Talanian RV, Kim YM (1997) Nitric oxide reversibly inhibits seven members of the caspase family via $S$-nitrosylation. Biochem Biophys Res Commun 240:419-424.

Li L, Prevette D, Oppenheim RW, Milligan CE (1998) Involvement of specific caspases in motoneuron cell death in vivo and in vitro following trophic factor deprivation. Mol Cell Neurosci 12:157-167.

Li P, Nijhawan D, Budihardjo I, Srinivasula SM, Ahmad M, Alnemri ES, Wang, X (1997) Cytochrome c and dATP-dependent formation of Apaf-1/caspase-9 complex initiates an apoptotic protease cascade. Cell 91:479-489.

Lin KT, Xue JY, Nomen M, Spur B, Wong Y (1995) Peroxynitriteinduced apoptosis in HL-60 cells. J Biol Chem 270:16487-16490.

Lipton SA, Choi YB, Pan ZH, Lei SZ, Chen HS, Sucher NJ, Loscalzo J, Singel DJ, Stamler JS (1993) A redox-based mechanism for the neuroprotective and neurodestructive effects of nitric oxide and related nitroso-compounds. Nature 364:626-632.

Liu W, Staecker H, Stupak H, Malgrange B, Lefebvre P, Van De Water TR (1998) Caspase inhibitors prevent cisplatin-induced apoptosis of auditory sensory cells. NeuroReport 9:2609-2614.

Lu L, Bonham CA, Chambers FG, Watkins SC, Hoffman RA, Simmons RL, Thomson AW (1996) Induction of nitric oxide synthase in mouse dendritic cells by IFN-gamma, endotoxin, and interaction with allogeneic T cells: nitric oxide production is associated with dendritic cell apoptosis. J Immunol 157:3577-3586.

Mannick JB, Asano K, Izumi K, Kieff E, Stamler JS (1994) Nitric oxide produced by human B lymphocytes inhibits apoptosis and EpsteinBarr virus reactivation. Cell 79:1137-1146.

Mannick JB, Miao XQ, Stamler JS (1997) Nitric oxide inhibits Fasinduced apoptosis. J Biol Chem 272:24125-24128.

Muzio M, Chinnaiyan AM, Kischkel FC, O'Rourke K, Shevchenko A, Ni J, Scaffidi C, Bretz JD, Zhang M, Gentz R, Mann M, Krammer PH, Peter ME, Dixit VM (1996) FLICE, a novel FADD-homologous ICE/ CED-3-like protease, is recruited to the CD95 (Fas/APO-1) deathinducing signaling complex. Cell 85:817-827.

Narayanan V (1997) Apoptosis in development and disease of the nervous system. I. Naturally occurring cell death in the developing nervous system. Pediatr Neurol 16:9-13.

Nath R, Probert Jr A, McGinnis KM, Wang KK (1998) Evidence for activation of caspase-3-like protease in excitotoxin- and hypoxia/ hypoglycemia-injured neurons. J Neurochem 71:186-195.

Nicholson DW, Ali A, Thornberry NA, Vaillancourt JP, Ding CK, Gallant M, Gareau Y, Griffin, PR, Labelle M, Lazebnik YA, Munday NA, Raju SM, Smulson ME, Yamin TT, Yu VL, Miller DK (1995)
Identification and inhibition of the ICE/CED-3 protease necessary for mammalian apoptosis. Nature 376:37-43.

Okada S, Zhang H, Hatano M, Tokuhisa T (1998) A physiologic role of Bcl-xL induced in activated macrophages. J Immunol 160:2590-2596.

Park DS, Stefanis L, Yan CYI, Farinelli SE, Greene LA (1996) Ordering the cell death pathway. Differential effects of BCL2: an interleukin1-converting enzyme family protease inhibitor, and other survival agents on JNK activation in serum/nerve growth factor-deprived PC12 cells. J Biol Chem 271:21898-21905.

Peled-Kamar M, Lotem J, Okon E, Sachs L, Groner Y (1998) Thymic abnormalities and enhanced apoptosis of thymocytes and bone marrow cells in transgenic mice overexpressing $\mathrm{Cu} / \mathrm{Zn}$-superoxide dismutase: implications for Down's syndrome. EMBO J 14:4985-4993.

Pettmann B, Henderson CE (1998) Neuronal cell death. Neuron 20:633-647.

Przywara DA, Kulkarni JS, Wakade TD, Leontiev DV, Wakade AR (1998) Pituitary adenylyl cyclase activating polypeptide and nerve growth factor use the proteasome to rescue nerve growth factordeprived sympathetic neurons cultured from chick embryos. J Neurochem 71:1889-1897.

Sciorati C, Rovere P, Ferrarini M, Heltai S, Manfredi AA, Clementi E (1997) Autocrine nitric oxide modulates CD95-induced apoptosis in gamma delta T lymphocytes. J Biol Chem 272:23211-23215.

Soto AM, Sonnenschein C (1985) The role of estrogens on the proliferation of human breast tumor cells (MCF-7). J Steroid Biochem 23:87-94.

Stamler JS (1994) Redox signaling: nitrosylation and related target interactions of nitric oxide. Cell 78:931-936.

Stefanis L, Park DS, Yan CY, Farinelli SE, Troy CM, Shelanski ML, Greene LA (1996) Induction of CPP32-like activity in PC12 cells by withdrawal of trophic support. Dissociation from apoptosis. J Biol Chem 271:30663-30671.

Steller H (1995) Mechanisms and genes of cellular suicide. Science 267:1445-1449.

Tanabe H, Eguchi Y, Shimizu S, Martinou JC, Tsujimoto Y (1998) Death-signaling cascade in mouse cerebellar granule neurons. Eur J Neurosci 10:1403-1411.

Tenneti L, D'Emilia DM, Lipton SA (1997) Suppression of neuronal apoptosis by $S$-nitrosylation of caspases. Neurosci Lett 236:139-142.

Thomas MK, Francis SH, Corbin JD (1990) Substrate- and kinasedirected regulation of phosphorylation of a cGMP-binding phosphodiesterase by cGMP. J Biol Chem 265:14971-14978.

Thompson CB (1995) Apoptosis in the pathogenesis and treatment of disease. Science 267:1456-1462.

Troy CM, Derossi D, Prochiantz A, Greene LA, Shelanski ML (1996) Downregulation of $\mathrm{Cu} / \mathrm{Zn}$ superoxide dismutase leads to cell death via the nitric oxide-peroxynitrite pathway. J Neurosci 16:253-261.

Tsou K, Snyder GL, Greengard P (1993) Nitric oxide/cGMP pathway stimulates phosphorylation of DARPP-32, a dopamine- and cAMPregulated phosphoprotein, in the substantia nigra. Proc Natl Acad Sci USA 90:3462-3465.

Villa P, Kaufmann SH, Earnshaw WC (1997) Caspases and caspase inhibitors. Trends Biochem Sci 22:388-393.

Wang S, Miura M, Jung YK, Zhu H, Li E, Yuan J (1998) Murine caspase-11, an ICE-interacting protease, is essential for the activation of ICE. Cell 92:501-509.

Whalin ME, Scammell JG, Strada SJ, Thompson WJ (1991) Phosphodiesterase II, the cGMP-activatable cyclic nucleotide phosphodiesterase, regulates cyclic AMP metabolism in PC12 cells. Mol Pharmacol 39:711-717.

Wink DA, Darbyshire JF, Nims RW, Saavedra JE, Ford PC (1993) Reactions of the bioregulatory agent nitric oxide in oxygenated aqueous media: determination of the kinetics for oxidation and nitrosation by intermediates generated in the $\mathrm{NO} / \mathrm{O}_{2}$ reaction. Chem Res Toxicol 6:23-27.

Yang J, Liu X, Bhalla K, Kim CN, Ibrado AM, Cai J, Peng TI, Jones DP, Wang X (1997) Prevention of apoptosis by Bcl-2: release of cytochrome c from mitochondria blocked. Science 275:1129-1132.

Yoshimura S, Banno Y, Nakashima S, Takenaka K, Sakai H, Nishimura Y, Sakai N, Shimizu S, Eguchi Y, Tsujimoto Y, Nozawa Y (1998) Ceramide formation leads to caspase-3 activation during hypoxic PC12 cell death. Inhibitory effects of $\mathrm{Bcl}-2$ on ceramide formation and caspase-3 activation. J Biol Chem 273:6921-6927.

Zhang J, Dawson VL, Dawson TM, Snyder SH (1994) Nitric oxide activation of poly(ADP-ribose) synthetase in neurotoxicity. Science 263:687-689. 